\title{
Hydrology of the Carpathian Basin: interactions of climatic drivers and hydrological processes on local and regional scales - HydroCarpath Research
}

\author{
Ján Szolgay $^{1 *}$, Günter Blöschl², Zoltán Gribovszki ${ }^{3}$, Juraj Parajka ${ }^{2}$ \\ ${ }^{1}$ Department of Land and Water Resources Management, Slovak University of Technology, Radlinského 11, 810 05, Bratislava, Slovakia. \\ ${ }^{2}$ Institute of Hydraulic Engineering and Water Resources Management, TU Wien, Karlsplatz 13, A-1040 Vienna, Austria. \\ ${ }^{3}$ Institute of Geomatics and Civil Engineering, University of Sopron, Bajcsy-Zsilinszky utca 4., Sopron, H-9400, Hungary. \\ * Corresponding author. E-mail: jan.szolgay@stuba.sk
}

\begin{abstract}
The paper introduces the Special Section on the Hydrology of the Carpathians in this issue. It is the result of an initiative of the Department of Land and Water Resources Management of the Slovak University of Technology in Bratislava, the Institute of Hydraulic Engineering and Water Resources Management of the TU Vienna and the Institute of Geomatics and Civil Engineering of the University of Sopron to allow young hydrologists in the Carpathian Basin (and from outside) to present their research and re-network on the emerging topics of the hydrology of the Carpathians at the HydroCarpath Conferences since 2012.
\end{abstract}

Keywords: Carpathian Basin; Evapotranspiration; Runoff coefficient; Hydrological regime; CN number; Climate change.

\section{Challenges to the hydrology and water management in the Carpathian Basin}

Signals of changing climate and recent extreme flood and drought events in the Carpathian Basin have stimulated scientific and public discussion on the issue of whether the frequency and severity of these events have been increasing, to what extent such changes could be attributed to anthropogenic influence and how to observe, monitor and model processes describing them. Despite the fact that a large amount of research has been undertaken to investigate the primary sources of natural drivers and societal pressures of hydrological phenomena globally, there is still an urgent need to achieve a comprehensive understanding of the impacts of current land use and management practices, and their changes, on runoff processes in general and those of extremes in particular. It is recognized in the Basin and globally that understanding the interactions of drivers and hydrological processes on local and regional scales is also an essential prerequisite for addressing practical water resources management problems (Blöschl et al., 2019).

The rich spatial and temporal heterogeneity of climatic drivers, regional and local control conditions in the Carpathian Basin, and the variety of active flow processes during particular seasons and events, makes it difficult to arrive at generalized descriptions of the genesis of particular types of regimes and events. The same applies to specific regional and local hazards and risk factors and to the design of generally applicable mitigation schemes. In this respect, the regional understanding and modelling of catchment hydrological processes are becoming increasingly important for addressing science as well as practical water resources management questions. Chances offered by new sources of data, based on latest developments in radar meteorology, experiments on hillslopes, and tracer studies in catchments have given hydrologists opportunities to compare different models of the same type (e.g., distributed) or different types of models (e.g., distributed vs lumped, process-based vs conceptual) on a regional basis (Bierkens, 2015). The confron- tation of catchment experiments with results from catchment modelling has become more critical in recent years (Ceola et al., 2015).

On the other hand, the new data is also supporting the study and generalization of hydrological regimes. All these activities support better process representations in both deterministic and stochastic models in diverse hydrological environments and enable more reliable predictions in ungauged basins. International cooperation in science within hydrologically connected transnational basins is essential to meet these challenges. In the Carpathian Basin, established hydrologic scientific networks have suffered due to the significant societal and economic changes in the last decades. Previously, flourishing experimental research became underfinanced and international UNESCO supported education almost diminished (Brilly et al., 2010; Prohaska et al., 2020). Other negative aspects were the reorganization and vanishing of some hydrology related research organizations. For example, in Hungary, hydrological research was implemented or coordinated traditionally at the Water Resources Research Institute (acronym VITUKI). Which was Because of reorganization VITUKI has been dissolved in 2013. Some of its main research tasks had not continued (Gribovszki, 2015). Recently, it has been increasingly recognized that the cooperation in hydrology along the Danube needs to be revitalized. In the Common statement from the participants of the XXVII Danubian Conference on hydrological forecasting and hydrological base of water management (Ninov and Bojilova, 2017), the urgent needs of engineering hydrology and water resources management were summed up under 14 topics.

Against this background, the Department of Land and Water Resources Management of the Slovak University of Technology in Bratislava, the Institute of Hydraulic Engineering and Water Resources Management of the TU Vienna and the Institute of Geomatics and Civil Engineering of the University of Sopron launched an initiative to give an opportunity to young hydrologists in the Basin (and from outside) to present their research and re-network on the emerging topics of scientific hydrology connected to the hydrology of the Carpathians - the 
HydroCarpath Conference series, starting in 2012 (HC, 2020). This conference series has continued to present results mainly from $\mathrm{PhD}$ research on problems of local and regional Carpathian hydrology (and that in the surroundings) around these topics:

- Results from catchment experiments leading to better process understanding and representations.

- The confrontation of hydrological catchment models with new types of data and process representation for distinct purposes: suitability of models for particular questions.

- Regionalization and generalizations of hydrological regimes on various temporal and spatial scales using increased process knowledge.

- $\quad$ - Application of models and ensembles for improved characterization and predictions of changes in hydrological processes and climate change impacts on the water cycle.

This Special Section is organized along with these topics and presents contributions presented at recent conferences of this series.

\section{Recent advances in the hydrology of the Carpathian Basin}

Experimental research, after years of starvation and stagnation, has been revived recently in the Basin. Results from ongoing research from three research stations, the Hydrological Open Air Laboratory (HOAL) in Petzenkirchen in Austria (Blöschl et al., 2016), the Jalovecky creek catchment in Slovakia (e.g., Holko et al., 2020a; Krajčí et al., 2016) and the Hidegvíz Valley experimental watershed in Hungary (Csáfordi et al., 2012) are presented in this Special Section.

Evapotranspiration plays an important role in the estimation of the water balance on many hydrologically relevant spatial and temporal scales (Casper et al., 2019). Without measuring evaporation and transpiration on the field scale, which is complicated due to the extreme heterogeneity of the whole relevant factors in the environment, the upscaling of point measurements to hillslope, catchment and regional scales cannot be completed (Burt et al., 2005). Without the parameterization of the evapotranspiration process in hydrological modelling (Széles et al., 2018), including its partitioning into the two basic components, we cannot succeed in many water management decisions (e.g. scheduling and determining water requirements for irrigation) or in capturing land surface-climate interactions in climate modelling (Wang and Dickinson, 2012). Therefore, research conducted even under particular conditions is a valuable contribution to the knowledgebase. Hogan et al. (2020, this issue) used an eddy covariance device to measure the evapotranspiration of a growing maize field in the HOAL research catchment in Austria. Using the concentration and isotopic ratio of water vapour within the canopy, the performance of two partitioning methods, the stable isotope technique and a Lagrangian near field theory (LNF), was compared in partitioning the evapotranspiration into evaporation and transpiration. The two methods gave overall similar results, and the measured values were in line with those from similar experiments with maize. Given the complicated nature of the phenomenon, recommendations for follow-up research are not straightforward, because the robustness and the much larger amount of useable data of the stable isotope method, as well its lower variance, are offset by the need for additional measurements and analyses.

The confrontation of hydrological catchment models with new types of data and process representation for distinct purposes, including testing the appropriateness of models for particular questions are also preferred topics at the HydroCarpath conferences. Formation of runoff on the hillslope and catchment scale during intense precipitation is one of the inten- sively discussed and researched topics in this respect (e.g. Scherrer et al., 2007; Silasari et al., 2017). The response of catchment runoff to precipitation is highly non-linear due to heterogeneity in inputs and catchment characteristics, threshold behaviour depending on catchment wetness and storage states, varying relative contributions of different landscape units, etc. Besides infiltration excess (Hortonian) and surface flow, subsurface stormflow is generally recognized as a dominant factor in flood generation (e.g., Bachmair and Weiler, 2011). Soils play an important role in runoff formation. Preferential flow in the soil/subsoil/hillslope system through subsurface networks that have developed from a range of botanical, faunal and geophysical processes, also contribute to the transport of fine particles, water and solutes and to soil degradation (Band et al., 2014). Preferential flow in the soils (Beven and Germann, 2013), instability-driven flow (Tesař et al., 2001) or the fill and spill mechanism (Tromp-van Meerveld and McDonnell, 2006) are commonly used to explain the rapid formation of subsurface flow that eventually contributes to catchment stormflow. Soil stoniness can also contribute to rapid flow response as it reduces the soil retention capacity. This phenomenon is still not well studied, and it is often neglected in runoff formation theories and is not included mathematical models (Hlaváčiková et al., 2018). Mujtaba et al. (2020, this issue) used measured catchment runoff of the Jalovecký Creek experimental catchment (West Tatra Mountains, Slovakia) generated by moderate and high-intensity rainfall as a basis for comparison with modelled responses from the HYDRUS 2D model, which accounts for stoniness (Šimůnek et al., 2018). Comparisons of simulated lateral subsurface flow hydrographs with catchment runoff hydrographs have indicated that the shapes of both were similar for about one-half of the examined rainfall events. These findings call for increasing the efforts in obtaining good field and laboratory data characterizing soil stoniness and its variability, since the central idea of this study, the notion that reduced retention of stony soils can have a similar effect on catchment runoff formation as the commonly accepted and more often studied preferential flow, needs to get serious attention in the future.

Experimental data on runoff formation can be useful when a typology of flooding phenomena is sought. Indicators for the intensity of flood generation for different runoff mechanisms can be either direct or indirect. The direct indicators are directly linked to catchment properties, whereas the indirect indicators are linked to flood and flooding properties. The threshold values of these indicators are of a local nature, as they depend on the hydrology of the plot/hillslope/river basin in question. Three specific spatial scales are important for understanding the lateral movement of water on or below the soil surface: the plot, the hillslope, and catchment/river scales (e.g. Smith and Redding, 2012). There cannot be a unique set of indicators for all of these, even under equal environmental/social settings.

Among direct indicators on the catchment scale, which can capture the character of runoff concentration, typically are morphometric parameters (such as stream density, catchment shape, size and distribution of wetlands and sealed surfaces, etc.), anthropogenic disturbances (cross-drain frequency or density of roads, the density of stream crossings, drainage systems, etc.), runoff concentration indices (time of concentration, time to the peak, catchment lag time, etc., see Fang et al. (2005) for a review), landcover (vegetation, land use types and evolution) or geology (Viglione et al., 2018).

As indirect indicators on the catchment/regional scale one could typically use descriptors of flood typology, such as runoff generation process typology (Viglione et al., 2010), the propor- 
tion of events of different origins and typical flood time scales (Gaál et al., 2012).

Among these indicators, the event runoff coefficient and the recession coefficient are of special theoretical importance for understanding catchment response and also of practical importance in hydrological design. Both can be regarded as important characteristics of hydrologic response on the event scale. The study of Chen et al. (2020, this issue) aimed at identifying factors which control the variability of event runoff coefficients (and the recession coefficient) in the HOAL research catchment and evaluating the relative importance of the controls in different subcatchments representing different runoff generation mechanisms. Besides that, also the predictive power of three regression-based machine learning techniques was evaluated with respect to their potential for estimating the event runoff coefficient (and the recession coefficient) from their controls. Overall, it was possible to demonstrate that both the performance of estimating the runoff coefficient (and the recession coefficient) and the relative importance of explanatory variables depend on the type of hydrological system, i.e. the runoff generation mechanism. The study, therefore, motivates further research into understanding their controls and their variability, since it has the potential for improving predictions of runoff in ungauged basins.

The estimation of event-based flood events is one of the most important parts of the design process for a large number of engineering projects and studies. A significant problem may arise in small catchments that are poorly gauged or when no recorded data exist. As an indirect indicator of flooding intensity, the $\mathrm{CN}$ parameter is important in this respect, which is usually directly used in direct runoff and design discharge estimation. Since its introduction in 1954, the Soil Conservation Service curve number (SCS-CN) method is generally considered a standard tool in practice. It has an empirical origin, lumped character, and even though the SCS-CN method is restricted to certain geographic regions and land use types, it is widely used (Bartlett et al., 2016).

In this method, the relationship between soil and land use characteristics and antecedent rainfall conditions are represented by a Curve Number $(\mathrm{CN})$ parameter, which is tabulated in the original method. With this simple parameter, a rainfall depth is transformed into a runoff depth. Testing of the method under various hydrological conditions, unfortunately, showed several limitations, which were pointed out, e.g., by McCutcheon et al. (2006). Despite rising criticism due to the lack of European data for its verification, see Soulis et al. (2009), in engineering studies (and also in some rainfall-runoff models and, in some cases, even in mitigation policies), the SCN method has remained popular in the Carpathian Basin.

Recently, to address these limitations, the use of empirical $\mathrm{CN}$ values calculated from recorded rainfall-runoff events, instead of the tabulated ones, was proposed and tested in the Basin. Banasik et al. (2014) and Rutkowska et al. (2015) introduced a probabilistic approach to the variability of empirical CNs. The main objective of the Kohnová et al. (2020, this issue) is to continue along this line by proposing and evaluating the performance of a regional approach to treat empirical $\mathrm{CN}$ values in homogeneous regions statistically and to test the sensitivity of such estimation to different initial abstraction ratios. The popular method of Hosking and Wallis was combined with the ANOVA test to delineate homogenous groups of catchments with similar empirical $\mathrm{CN}$ values. The $50 \%$ quantile of the regional theoretical regional distribution function of $\mathrm{CN}$ estimated from all catchments in the region, was chosen as the regionally representative $\mathrm{CN}$. The regional treatment and intro- duction of a common regional $\mathrm{CN}$ open up the opportunity to pool the information content of the rainfall-runoff process in homogenous catchments and to apply it to similar catchments. Confronting the landuse-based tabulated $\mathrm{CN}$ values with the statistically derived counterparts in the region contributes to more reliable estimation of design discharges in small catchments. The paper could, therefore, give rise to an alternative way of estimating $\mathrm{CN}$ values in forested catchments and catchments with a lack of data or without observations.

Regionalisation and generalisations of hydrological regimes on various temporal and spatial scales using increased process knowledge was a traditional strength of the hydrology of the Carpathians in the past (e.g. Brilly et al., 2010). The scale and intensity of slow changes in land-use/management due to economic reasons and new political priorities (following changes in 1989, such as the abandonment of land, a new paradigm in the management of forests, increasing protection of ecosystems and introduction of natural water retention measures, changes in agricultural policies, etc.) call for studying the changes of hydrological regimes. Numerous attempts were therefore undertaken to use distributed rainfall-runoff models to assess regime changes resulting from such effects (e.g. Rončák et al., 2016) and to detect signals indicating irregular behaviour of hydrological time series in the Basin (e.g. Pekárová et al., 2011). Less common, and indeed more difficult to conduct, were attempts to explain regularities or potential irregularities in time series by causative factors (e.g. Longman et al., 2019). In this respect, Kundzewicz and Robson (2004) reminded that analyses of time series data should include stages of exploratory data analysis, application of statistical analysis and interpretation of tests results, warning that natural variability could appear like trends and other changes. Merz et al. (2012) suggested that detection only is not sufficient, it should always be accompanied by the more challenging attribution, and both should be positioned within in a hypothesis-testing framework. Holko et al. (2020a, b, this issue) in two companion papers, guided by such principles, analysed the water balance, hydrological response, runoff and snow cover characteristics as well as isotopic data in precipitation and catchment runoff (oxygen 18 ) in search for changes in the hydrological cycle of a mountain catchment representative of the hydrology of the highest part of the Western Carpathians. Both studies differ from similar studies by the fact that they are conducted in an experimental catchment, where the hydrological cycle is relatively well understood, and many different data series were available for the analysis to identify causal factors. The authors did not restrict themselves to the use of one analytic method. Instead, they focused on the consistency of results from different methods. Even though no clear signals for relating the observed behaviour of the respective time series were found, new insights were gained into the complexities of the components of the hydrological cycle and the behaviour of hydrologic phenomena. At the same time, they stated that despite better data availability and deeper knowledge of the hydrological cycle in the research catchment compared to other, less-studied catchments, the attribution analysis remained uncertain due to the unavailability of data on other possible drivers.

Application of models and ensembles for improved characterisation and prediction of changes in hydrological processes and of climate change impacts on the water cycle is naturally a hot topic for hydrology research in the Basin, too. Diverse approaches on how to assess the impact of changes in climate on the hydrological regime exist. Credible data, methods and tools are needed to evaluate the uncertainty in the projections (Olsson et al., 2016). Regional climate models (RCM) domi- 
nate the climate scenarios in regional or local assessments in hydrology either as single- or multi-model studies using again single or ensemble downscaled RCM outputs (e.g. Krysanova and Hattermann, 2017). While a single scenario and model studies were dominating in the past, recent methodical improvements have advanced the quantification of uncertainties in the modelling chain. Past scenario-based climate change impact modelling with rainfall-runoff models in the Carpathian Basin Slovakia rarely accounted for uncertainties due to various climatic models. These assessment methods have limited potential today when various regional climate model outputs with short time steps under several emission scenarios are available. The majority of present studies uses downscaled RCM climate/emission scenarios to drive rainfall-runoff models (Stagl and Hattermann, 2015). Csáki et al. (2020, this issue) conducted a systematic intercomparison of climate change impacts on evapotranspiration and runoff in a catchment supplying water to the largest lake in Central Europe using multiple regional climate change models and a robust climate-runoff model built around a modified Budyko hypothesis. The Budyko framework was extended for areas (e.g. in the lowlands of the Carpathian Basin) where an additional amount of water is available for evapotranspiration above that which the area receives from local precipitation (water bodies or storages with allochthone inflows). The main advantage of the proposed model is its gridbased spatial structure, simple parameterisation and modest requirements for inputs. A complex validation methodology of the climate-runoff model was proposed, which extends the methodology to climate change impact assessments. The tradeoff for its robustness is that its present version cannot handle significant changes in the areas receiving allochthone inflows for future climates. Still, it is possible to extend this model in the future.

\section{Future challenges of hydrological research in the Basin}

In order to support the needs of integrated water resources management in this transnational Basin, the process-oriented modelling of hydrological processes and parameterization of models need to remain an essential part of future research concerning this set of problems (Wahren et al., 2009). Consequently, there is a continuing necessity to conduct field studies for identifying and quantifying processes of catchment response and assembling field-based evidence for testing the assumptions underpinning model design and for addressing the uncertainties and controversies that continue to frustrate our understanding of catchment behaviour (Bathurst et al., 2018). As an extension of the necessary field experimental research of site-related runoff generation and erosion processes, this also requires the further development of hydrological models that are capable of taking into account the effect of various land uses and agricultural land management practices on the formation of surface and subsurface flows (Montanari et al., 2015). Moreover, this new generation of hydrological models should provide scientifically-based correct answers about runoff generation processes under changed conditions and have the ability to assess the efficiency of currently preferred near-nature management practices of agricultural land aimed at the reduction of floods, erosion and transport processes (Blöschl et al., 2019).

One of the key problems is an appropriate parameterization of the physiographical environment of hillslopes in headwater catchments and process-oriented schemes of extreme runoff and erosion formation. These would comply with the requirements of models and would take into account extremely variable local conditions of runoff generation processes, especially in small catchments and under extreme conditions. A combination of state-of-the-art experimental terrain measurements with a modelling approach is required, as well as the development of methods for the transferability of the results from an experimental site scale to the scale of hillslopes and small headwater catchments. These and other research gaps in understanding flood changes caused by changes in land and forest management, agricultural practices, artificial drainage and terracing have been identified in Rogger et al. (2017). Potential strategies in addressing these gaps were also proposed. Solutions may include complex systems approaches which would link processes across time scales, embedding and upscaling outcomes from experimental research on physical-chemical-biological process interactions on a plot to catchment scales. A focus on connectivity and patterns across spatial scales should be in the centre of interest. This, in turn, calls for interdisciplinary research that will coherently deal with problems across hydrology, soil and agricultural sciences, forest engineering, forest ecology and geomorphology (Rogger et al., 2017). Natural water retention measures, which are a new paradigm in flood hazard mitigation, are a potential integrative agent of these coupled processes. Actions proposed to reduce erosion on hillslopes and store water may decrease the flood risk by overland flow, but will increase infiltration and soil moisture, and thus increase the risk of subsurface stormflow, soil mass movement, the temporary flooding of meadows and agricultural soils, and waterlogging.

Managers and decision-makers have perhaps not fully recognized the associated risks and chances in practice in the Basin (Ninov and Biljaeva, 2017). This, therefore, calls for the introduction of an integrated assessment of methodologies, drivers and impacts. Although scientific advances for developing integrated methodologies are evident, developing robust tools remains a significant challenge. A connected issue is an integration of existing and newly available data and information bases for this purpose with implications for data and monitoring requirements and the selection of new sets of indicators. In order to develop an integrated strategy for addressing the interactions of threats on different spatial and temporal scales, more detailed knowledge of the interactions needs to be gathered for all these threats, including an evaluation of potentially counterproductive impacts of mitigating measures. This knowledge has to be incorporated into water and mass flow generation models to better predict not only water-related processes but also all related ecohydrological aspects (e.g., Band et al., 2014).

Acknowledgements. This study has been supported by project EFOP-3.6.2-16-2017-00018 of the University of Sopron and by the VEGA Scientific Grant Agency Grant No. 1/0632/19. The support is gratefully acknowledged.

\section{REFERENCES}

Bachmair, S., Weiler, M., 2011. New dimensions of hillslope hydrology. In: Levia, D.F. (Ed.): Forest Hydrology and Biogeochemistry. Synthesis of Past Research and Future Directions. Ecological Studies, Vol. 2016. Springer, 455-482.

Banasik, K., Rutkowska, A., Kohnová, S., 2014. Retention and curve number variability in a small agricultural catchment: the probabilistic approach. Water, 6, 5, 1118-1133.

Band, L.E., McDonnell, J.J., Duncan, J.M., Barros, A., Bejan, A., Burt, T., Dietrich, W.E., Emanuel, R., Hwang, T., Katul, G., Kim, Y., McGlynn, B., Miles, B., Porporato, A., Scaife, C., Troch, P.A., 2014. Ecohydrological flow networks in the subsurface. Ecohydrology, 7, 4, 1073-1078. 
Bartlett, M.S., Parolari, A.J., McDonnell, J.J., Porporato, A., 2016. Beyond the SCS-CN method: A theoretical framework for spatially lumped rainfall-runoff response. Water Resour. Res., 52, 4608-4627.

Bathurst, J., Birkinshaw, S., Johnson, H., Kenny, A., Napier, A., Raven, S., Robinson, J., Stroud, R., 2018. Runoff, flood peaks and proportional response in a combined nested and paired forest plantation/peat grassland catchment. Journal of Hydrology, 564, 916-927.

Beven, K., German, P., 2013. Macropores and water flow in soils revisited. Water Resources Research, 49, 6, 30713092.

Bierkens, M.F.P., 2015. Global hydrology 2015: state, trends, and directions. Water Resources Research, 51, 4923-4947.

Blöschl, G., Bierkens, M.F.P., Chambel, A., Cudennec, C., Destouni, G., et al., 2019. Twenty-three unsolved problems in hydrology (UPH) - a community perspective. Hydrological Sciences Journal - Journal des Sciences Hydrologiques, 64, 10, 1141-1158.

Blöschl, G., Blaschke, A.P., Broer, M., Bucher, C., Carr, G., Chen, X., Eder, A., Exner-Kittridge, M., Farnleitner, A., Flores-Orozco, A., Haas, P., Hogan, P., Kazemi Amiri, A., Oismüller, M., Parajka, J., Silasari, R., Stadler, P., Strauss, P., Vreugdenhil, M., Wagner, W., Zessner, M., 2016. The Hydrological Open Air Laboratory (HOAL) in Petzenkirchen: a hypothesis-driven observatory. Hydrol. Earth Syst. Sci., 20, 1, 227-255.

Brilly, M. (Ed.), 2010. Hydrological Processes of the Danube River Basin Perspectives from the Danubian Countries. Springer, 436 p. ISBN 978-90-481-3423-6

Burt, C.M., Mutziger, A.J., Allen, R.G, Howell, T.A., 2005. Evaporation research: review and interpretation. J. Irrig. Drain. Eng., 131, 1, 37-58.

Casper, M.C., Mohajerani, H., Hassler, S., Herdel, T., Blume, T., 2019. Finding behavioral parameterization for a 1-D water balance model by multi-criteria evaluation. J. Hydrol. Hydromech., 67, 3, 2019, 213-224.

Ceola, S., Arheimer, B., Baratti, E., Blöschl, G., Capell, R., Castellarin, A., Freer, J., Han, D., Hrachowitz, M., Hundecha, Y., Hutton, C., Lindström, G., Montanari, A., Nijzink, R., Parajka, J., Toth, E., Viglione, A., and Wagener, T., 2015. Virtual laboratories: new opportunities for collaborative water science. Hydrol. Earth Syst. Sci., 19, 2101-2117.

Chen, X., Parajka, J., Széles, B., Strauss, P., Blöschl., G., 2020. Controls on event runoff coefficients and recession coefficients for different runoff generation mechanisms identified by three regression methods. J. Hydrol. Hydromech., 68, 2, 155-169.

Csáfordi, P., Eredics, A., Gribovszki, Z., Kalicz, P., Koppán, A., Kucsara, M., Moricz, N., Rasztovits, E., Víg, P., 2012. Hidegvíz Valley Experimental Watershed. (Eds.): Gribovszki Z., Kalicz P. Nyugat-magyarországi Egyetem Kiadó, Sopron, 27 p. ISBN 978-963-334-080-6

Csáki, P., Gyimóthy, K., Kalicz, P., Szolgay, J., Zagyvai-Kiss, K.A., Gribovszki, Z., 2020. Multi-model climatic water balance prediction in the Zala River Basin (Hungary) based on a modified Budyko framework. J. Hydrol. Hydromech., 68, 2, 200-210.

Fang, X., Cleveland, T., Garcia, A.C., Thompson, D., Malla, R., 2005. Literature Review on Timing Parameters for Hydrographs. Report 0-4696-1. Department of Civil Engineering College of Engineering at Lamar University, Beaumont, $82 \mathrm{p}$.

Gaál, L., Szolgay, J., Kohnová, S., Parajka, J., Merz, R., Viglione, A., Blöschl, G., 2012. Flood timescales: Under- standing the interplay of climate and catchment processes through comparative hydrology. Water Resources Research, 48, 4, 21.

Gribovszki, Z., 2015. Hungarian National Report on IAHS (2011-2014). Geomatikai Közlemények, 18, 1, 106-113.

HC, 2020. The Hydrocarpath conference. http://hydrocarpath.nyme.hu/index.php/21952/?\&L=4

Hlaváčiková, H., Novák, V., Kostka, Z., Danko, M., Hlavčo, J., 2018. The influence of stony soil properties on water dynamics modeled by the HYDRUS model. J. Hydrol. Hydromech., 66, 181-188.

Hogan, P., Parajka, J., Heng, L., Strauss, P., Blöschl., G., 2020. Partitioning evapotranspiration using stable isotopes and Lagrangian dispersion analysis in a small agricultural catchment. J. Hydrol. Hydromech., 68, 2, 134-143. DOI: 10.2478/johh-2020-0009

Holko, L., Sleziak, P., Danko, M., Bičárová, S., PociaskKarteczka, J., 2020a. Analysis of changes in the hydrological cycle of a pristine mountain catchment. 1. Water balance components and snow cover. J. Hydrol. Hydromech., 68, 2, 180-191. DOI: 10.2478/johh-2020-0010

Holko, L., Danko, M., Sleziak, P., 2020b. Analysis of changes in the hydrological cycle of a pristine mountain catchment. 2 . Isotopic data, trend and attribution analyses. Hydrol. Hydromech., 68, 2, 192-199. DOI: 10.2478/johh-2020-0011.

Kohnová, S., Rutkowska, A., Banasik, K., Hlavčová, K., 2020. The L-moment based regional approach to curve numbers for Slovak and Polish Carpathian catchments. J. Hydrol. Hydromech., 68, 2, 170-179. DOI: 10.2478/johh-2020-0004

Krajčí, P., Danko, M., Hlavčo, J., Kostka, Z., Holko, L., 2016. Experimental measurements for improved understanding and simulation of snowmelt events in the Western Tatra Mountains. J. Hydrol. Hydromech., 64, 4, 316-328.

Krysanova, V., Hattermann, F.F., 2017. Intercomparison of climate change impacts in 12 large river basins: an overview of methods and summary of results. Climatic Change, 141, 3, 363-379.

Kundzewicz, Z.W., Robson, A.J., 2004. Change detection in hydrological records - a review of the methodology. Hydrological Sciences Journal, 49, 1, 7-19.

Longman, J., Veres, D., Ersek, V., Haliuc, A., Wennrich, V., 2019. Runoff events and related rainfall variability in the Southern Carpathians during the last 2000 years. Scientific Reports, 9, 1, 5334.

McCutcheon, S.C., Tedela, N.H., Adams, M.B., Swank, W., Campbell, J.L., Hawkins, R.H., Dye, C.R., 2006. Rainfallrunoff relationships for selected eastern U.S. forested mountain watersheds: Testing of the curve number method for flood analysis. Report prepared for the West Virginia Division of Forestry, Charleston, West Virginia.

Merz, B., Vorogushyn, S., Uhlemann, S., Delgado, J., Hundecha, Y., 2012. HESS Opinions "More efforts and scientific rigour are needed to attribute trends in flood time series". Hydrol. Earth Syst. Sci., 16, 1379-1387.

Montanari, A., Bahr, J., Bloeschl, G., Cai, X., Mackay, D.S., Michalak, A.M., Rajaram, H., Sander, G., 2015. Fifty years of Water Resources Research: Legacy and perspectives for the science of hydrology. Water Resour. Res., 51, 6797-6803.

Mujtaba, B., Hlaváčiková, H., Danko, M., de Lima, J.L.M.P., Holko., L., 2020. The role of stony soils in hillslope and catchment runoff formation. J. Hydrol. Hydromech., 68, 2, 144-154. DOI: 10.2478/johh-2020-0012

Ninov, P., Bojilova, E. (Eds.), 2017. XXVII Conference of Danubian Countries on the hydrological forecasting and hydrological bases of water management. Book of proceedings. 
Golden Sands, Bulgaria, 624 p. ISBN 978-954-90537-2-2

Olsson, J., Arheimer, B., Borris, M., Donnelly, C., Foster, K., Nikulin, G., Persson, M., Perttu, A-M., Uvo, C.B., Viklander, M., Yang, W., 2016. Hydrological climate change impact assessment at small and large scales: key messages from recent progress in Sweden. Climate, 4, 3, 39, 1-24.

Pekárová, P., Miklánek, P., Halmová, D., Onderka, M., Pekár, J., Kučárová, K., Liová, S., Škoda, P., 2011. Long-term trend and multi-annual variability of water temperature in the pristine Bela River basin (Slovakia). Journal of Hydrology, 400, 3, 333-340.

Prohaska, S., Brilly, M., Kryzanovski, A., 2020. Cooperation of hydrologists from the Danube River Basin. HESS Discussions, 10 p. https://doi.org/10.5194/hess-2020-66

Rogger, M., Agnoletti, M., Alaoui, A., Bathurst, J.C., Bodner, G., Borga, M., Chaplot, V., Gallart, F., Glatzel, G., Hall, J., Holden, J., Holko, L., Horn, R., Kiss, A., Kohnová, S., Leitinger, G., Lennartz, B., Parajka, J., Perdigão, R., Peth, S., Plavcová, L., Quinton, J.N., Robinson, M., Salinas, J.L., Santoro, A., Szolgay, J., Tron, S., van den Akker, J.J.H., Viglione, A., Blöschl, G., 2017. Land use change impacts on floods at the catchment scale: Challenges and opportunities for future research. Water Resour. Res., 53, 5209-5219.

Rončák, P., Hlavčová, K., Látková, T., 2016. Estimation of the effect of changes in forest associations on runoff processes in basins: Case study in the Hron and Topla River Basins. Slovak Journal of Civil Engineering, 24, 3, 1-7.

Rutkowska, A., Kohnová, S., Banasik, K., Szolgay, J., Karabová, B., 2015. Probabilistic properties of a curve number: a case study for small Polish and Slovak Carpathian Basins. J. Mt. Sci., 12, 3, 533-548.

Scherrer, S., Naef, F., Faeh, A.O., Cordery, I., 2007. Formation of runoff at the hillslope scale during intense precipitation. Hydrol. Earth Syst. Sci., 11, 907-922.

Silasari, R., Parajka, J., Ressl, C., Strauss, P., Blöschl, G., 2017. Potential of time-lapse photography for identifying saturation area dynamics on agricultural hillslopes. Hydrological Processes, 31, 3610-3627. DOI: 10.1002/hyp.11272

Šimůnek, J., Šejna, M., van Genuchten, M.T., 2018. New features of version 3 of the HYDRUS (2D/3D) computer soft- ware package, J. Hydrol. Hydromech., 66, 2, 133-142. DOI: 10.1515/johh-2017-0050

Smith, R., Redding, T., 2012. Cumulative effects assessment: runoff generation in snowmelt dominated montane and boreal plain catchments. Watershed Management Bulletin, 15, 24-34.

Soulis, K.X., Valiantzas, J.D., Dercas, N., Londra, P.A., 2009. Investigtion of the direct runoff generation mechanism for the analysis of the SCS-CN method applicability to a partial area experimental watershed. Hydrol. Earth Syst. Sci., 13, 605-615.

Stagl, J.C., Hattermann, F.F., 2015. Impacts of climate change on the hydrological regime of the Danube River and its tributaries using an ensemble of climate scenarios. Water, 7, 6139-6172.

Széles, B., Broer, M., Parajka, J., Hogan, P., Eder, A., Strauss, P., Blöschl, G., 2018. Separation of scales in transpiration effects on low flows: A spatial analysis in the Hydrological Open Air Laboratory. Water Resources Research, 54, 9, 6168-6188.

Tesař, M., Šír, M., Syrovátka, O., Pražák, J., Lichner, L., Kubík, F., 2001. Soil water regime in head water regions - observation, assessment and modelling. J. Hydrol. Hydromech., 49, 6, 355406.

Tromp-van Meerveld, H.J., McDonnell, J.J., 2006. Threshold relations in subsurface stormflow: 2 . The fill and spill hypothesis. Water Resour Res., 42, W02411.

Viglione, A., Chirico, G.B, Komma, J., Woods, R., Borga, M., Blöschl, G., 2010. Quantifying space-time dynamics of flood event types. Journal of Hydrology, 394, 1-2, 213-229.

Viglione, A., Rogger, M., Pirkl, H., Parajka, J., Blöschl, G., 2018. Conceptual model building inspired by field-mapped runoff generation mechanisms. J. Hydrol. Hydromech., 66, 3, 303-315. DOI: 10.2478/johh-2018-0010

Wahren, A., Feger, K.H., Schwärzel, K., Münch, A., 2009. Landuse effects on flood generation - considering soil hydraulic measurements in modelling. Advances in Geosciences, 7, 1-9.

Wang, K., Dickinson, R.E., 2012. A review of global terrestrial evapotranspiration: Observation, modeling, climatology, and climatic variability. Rev. Geophys., 50, RG2005, 54 p. 